\title{
Polysèmes
}

Revue d'études intertextuelles et intermédiales

\section{Introduction: Contemporary Victoriana: Victorian Literature and Popular Cultures}

Yannick Bellenger-Morvan and Xavier Giudicelli

\section{(2) OpenEdition}

1 Journals

\section{Electronic version}

URL: http://journals.openedition.org/polysemes/7903

DOI: 10.4000/polysemes.7903

ISSN: 2496-4212

Publisher

SAIT

\section{Electronic reference}

Yannick Bellenger-Morvan and Xavier Giudicelli, « Introduction: Contemporary Victoriana: Victorian Literature and Popular Cultures », Polysèmes [Online], 23 | 2020, Online since 30 June 2020, connection on 25 September 2020. URL : http://journals.openedition.org/polysemes/7903 ; DOI https://doi.org/10.4000/polysemes.7903

This text was automatically generated on 25 September 2020.

Polysèmes 


\title{
Introduction: Contemporary Victoriana: Victorian Literature and Popular Cultures
}

\author{
Yannick Bellenger-Morvan and Xavier Giudicelli
}

\begin{abstract}
"For most of us, the odour of defunct Victoriana is so unpleasant [...] that we are content to leave the past where we find it" (Ezra Pound, 1918). "It is not that what is past casts its light on what is present, or what is present its light on what is past; rather, image is that wherein what has been comes together in a flash with the now to form a constellation" (Benjamin 462).
\end{abstract}

1 In Alan Hollinghurst's 2011 novel The Stranger's Child, the reference to Alfred, Lord Tennyson ${ }^{1}$ partakes of the general reflection that the novel offers on the relationship to the past, as exemplified by Victorianism and the reactions for and against it across the twentieth century. Significantly, the Victorian "jelly-mould domes", architectural features of Corley Court-one of the several houses recreated in the novel-are praised in 1913 (20), covered in the 1920s (140), then literally brought to light in the 1960s (345). Similarly, over the course of the twentieth century, Tennysonpoet laureate from 1850 to his death in 1892, the very embodiment of "high Victorianism"-has been eulogised, then vilified before finally being rediscovered. At the end of Hollinghurst's novel, Tennyson is somewhat comically brought back to life in a video clip of a digitally animated photograph, on the website Poets Alive! Houndvoice.com, which makes it appear as if he were reading his poetry (549): The Stranger's Child stages a (sometimes ironic) dialogue between past and present and is thus not simply a melancholy "rehashing" of texts from the English canon, nor a mere testimony of a nostalgia for the foreign country of the Victorian past. 
When in 1918, according to the Oxford English Dictionary, Ezra Pound coined the word "Victoriana" (see Mitchell 1), he used it as a derisive term to refer to things past which had better be forgotten. In contrast with Pound's statement, this thematic cluster of essays attests to the steady interest for things Victorian in our contemporary society and explores the multifarious afterlives of Victorian culture and literature.

Since Dana Shiller's introduction of the term Neo-Victorian in her 1997 essay "The Redemptive Past in the Neo-Victorian novel" and Sally Shuttleworth's seminal 1998 work on the retro-Victorian novel, Neo-Victorian studies have been a thriving field of enquiry, looking into texts which "self-consciously [engage] with the act of (re)interpretation, (re)discovery and (re)vision concerning the Victorians" (Heilmann and Llewellyn 4). Such texts hinge on a process of refraction, as Christian Gutleben and Susana Onega put it, "a double process involving the ways in which [...] text[s] exploit and integrate both the reflection[s] of [...] previous text[s] and the new light shed on the original work[s] by [their] rewriting" (7). They thus bring to mind Walter Benjamin's concept of "dialectical image" in which past and present "come together in a flash to form a constellation" (Benjamin 462).

4 The 11 essays gathered here are, in part, a selection of revised papers originally given at a one-day conference hosted at the Campus des Comtes de Champagne (University of Reims Champagne-Ardenne), in Troyes, in March 2018. The aim of the symposium was to examine contemporary Victorian afterlives by focusing on the reinterpretation of Victorian works now deemed canonical in such media associated with popular culture as comics and graphic novels, films, TV series, musicals, or video games. Its objective was also to address the recycling of Victorian cultural practices and artefacts in our society: the success of the serial form, a contemporary adaptation-or recreation-of Victorian serialised narratives, the re-scripting of the genre of the "penny dreadful"cheap, popular Victorian novels published in instalments, filled with sensational and often gory action and to be consumed without moderation, thus partaking of a capitalistic system we have certainly not left behind-as well as the influence of Victorian culture on the fashion industry, for instance in Alexander McQueen's creations (see Fennetaux), alternative cultures such as retrofuturistic, uchronistic Steampunk, ${ }^{2}$ or interior decoration, as exemplified by the unflagging popularity of William Morris designs, or the contemporary reclaiming of Staffordshire ceramic figures by Rob Ryan or Carol Windham (see Solicari 48-62).

We favour an interdisciplinary approach, in line with the research programme from which our project originates, namely the "popular cultures" seminar convened by Sylvie Mikowski and Yann Philippe, one of the programmes of the Interdisciplinary Research Centre on Language and Thought (CIRLEP) of the University of Reims. The aim of the seminar and of the various publications emanating from it (see Mikowski and Philippe) is to be a platform for innovative work on topics which had hitherto been of little interest in French academia, such as popular music, comics, whodunits or Internet memes.

6 Through the essays collected here, we hope to bring together two fields of enquiry, Neo-Victorian studies and popular culture studies, and, by doing so, to contribute to a redefinition of academic objects of investigation, of the canon, and of discursive practices.

7 The essays are divided into four sections. The first part of this volume ("Victorian Classics and New Media Forms") examines the strategies utilized by twenty-first- 
century artists to modernise Victorian motifs and adapt them to different, perhaps more contemporary, technologies and narrative formats. The tailoring of nineteenthcentury literary content to fit the aesthetic tastes of twenty-firstcentury digital natives may appear bold at best, if not downright anachronistic. However, many authors of the Victorian age tackled the issue of progress and modernity that stemmed from the industrial revolution and prompted the social and cultural changes that marked nineteenth-century Britain. Over time, Victorian canonical texts have been subject to many transformations, whether turned into graphic novels or TV series, which has made them part of our shared-popularculture. Their plots and characters have also been borrowed and recycled to create new, innovative, experimental cultural objects. Such is the case of American McGee's Alice (2000) and its sequel Alice: Madness Returns (2011), two video games that are openly adapted from Lewis Carroll's Alice books. Clémence Folléa examines the immersive experience involved in the games' interactive narratives. She shows how their designers explored the dark side of Carroll's fantasy novels, exploiting the sinister aspects of Victorian society (depression, madness, psychiatric asylums) to produce violent and gory games characterised by steampunk aesthetics. Folléa is especially intent on demonstrating that those games stand out in the video game industry, as American McGee is interested in offering players a gameplay experience serving his progressive fiction and assertive female characterisation. Contemporary literature also recycles-and experiments with-Victorian tropes and characters to renew our reading experience. Amelha Timoner focuses on Jasper Fforde's Thursday Next cycle, a series of fantasy novels borrowing plots and characters from the Victorian repertoire (Charlotte Brontë's Jane Eyre, Dickens's Miss Havisham, Carroll's Cheshire Cat, to name but a few). Timoner analyses how Fforde's uchrony subverts and parodies the Victorian canon while expanding the author's own metafictional, autonomous literary universe, aiming at frustrating the readers' expectations. The combination of new technologies and innovative narrative techniques seems to be at the core of our reflection on contemporary Victoriana. Anaïs Martin explains how contemporary French radio dramas, relying on new formats and new sound techniques, have managed to reinvent Victorian classics such as Jane Eyre and Dracula. Her analysis of sound sheds retrospective light on an essential, though overlooked, feature of Victorian narratives: the importance of sound devices such as the telephone or the phonograph as markers of Victorian industrial modernity.

8 The second section ("Victorian Horror and Gothic Fiction Revisited") explores cases of remediation and transmediation of such Victorian texts as the anonymous "penny dreadful" The String of Pearls (attributed to James Malcolm Rymer and Thomas Peckett Prest) published in 18 instalments between November 1846 and March 1847 and featuring the infamous character of Sweeney Todd, the demon barber of Fleet Street, or Sheridan Le Fanu's 1872 Carmilla and Wilde's 1890-1891 The Picture of Dorian Gray. Manon Labrande follows the metamorphoses of The String of Pearls, from its adaptation as a musical by Stephen Sondheim and Hugh Wheeler in 1979 to the 2003 Sweeney Todd by Tim Burton, based on Sondheim's transposition. She argues, borrowing Ruth Mayer's concept, that such works are "reconfigurations" of the original text: instances of a new medium taking over the narration in order to allow for scrutinising the workings of ideology, here critiquing late-twentieth and early twenty-first century capitalistic consumerism. Marine Galiné's essay analyses Guillermo Del Toro's 2015 feature film Crimson Peak. She examines Crimson Peak's hybrid aesthetics and its revisiting of such 
topoi of gothic fiction as the gothic castle and female heroines. She underscores Del Toro's ambivalent stance, in line with Linda Hutcheon's dual definition of parody as both a critique and a tribute to the text parodied (5): Crimson Peak pays homage to the Victorian texts from which he draws his inspiration (Le Fanu, Dickens, the Brontë sisters, or Poe) whilst at the same time challenging its literary forebears. In the following essay, Caroline Duvezin-Caubet studies the remediation of Carmilla, Le Fanu's gothic tale of female vampirism and coded lesbian desire, in a vlog (short for video blog), whose 121 2-to-6-minute episodes were posted on YouTube between 2004 and 2006. Duvezin-Caubet's essay highlights the self-reflexive possibilities offered by what Henry Jenkins calls "transmedia storytelling" in the web series Carmilla: a form of (female) empowerment and the promotion of a queer agenda questioning social constructs, aesthetic categories (by mixing tragedy and camp humour), as well as the relationship between viewer and work of art through the interactive, participatory forms of creation vlogs are. The last essay in this section, by Camille Martin-Payre, addresses the "untimeliness" of Oscar Wilde's Dorian Gray by analysing the embodiment of the ageless Victorian character in the 2014-2016 TV series Penny Dreadful. In the densely intertextual web of a series partaking of a musical mashup, weaving together several nineteenth-century and Victorian texts such as Mary Shelley's Frankenstein (1808), Robert Louis Stevenson's Strange Case of Dr Jekyll and Mr Hyde (1886) and Bram Stoker's Dracula (1897), Dorian Gray stands out as failing to convincingly fit into the narrative. Martin-Payre contends that Dorian Gray is an anachrony and that he destabilises the chronological coherence of the series: he transcends time, acting as "an archetype tailored to reflect the particular decadences of other time periods" and is thus "one of us"-as Richard Ellmann has argued about Dorian Gray's creator in his authoritative 1988 biography of Wilde (xiv). Dorian Gray is our contemporary in the sense Agamben gives the word-an untimely presence that haunts imaginations and suggests a queer, non-linear conception of time.

The third section, as its title aptly indicates, is entirely dedicated to the emblematic figure of Sherlock Holmes. First considered as the epitome of the Victorian gentleman, the detective of 221B Baker Street has lately undergone various transformations as his investigations have been retold, more or less obliquely, in novels, films and TV series. Conan Doyle's male hero and his sidekick Dr Watson have respectively morphed into female characters in CBS's Elementary (2012-2019) and Miss Sherlock (Misu Sharoku, HBO/Hulu Asia, April-June 2018). The Victorian sleuth has also crossed literal and metaphorical boundaries, embracing other cultures. Sherlock is Japanese in Miss Sherlock, he is African American in Joe Ide's noir novel, I.Q (2016). Those shifts in his identity have brought about new issues, mirroring twenty-first-century concerns: the postmodern questioning of authorship (what becomes of Conan Doyle once Sherlock, freed from his writing context, has become a myth?); the empowerment of supposedly "minor" voices. In her essay, Simona Catrinel Avarvarei develops the concept of terroir to understand the everlasting success of Sherlock Holmes. As an icon of Victorian England, Sherlock Holmes has escaped the control of his creator and has been appropriated by the receptors of his stories. Drawing on Barthes's theories, Avarvarei notably discusses the death of the author and the rise of fan culture. The phenomenon is obviously reminiscent of Jenkins's concepts of fandom and participatory culture. Peggy Blin-Cordon offers an in-depth analysis of Joe Ide's rewriting of Doyle's 1902 Hound of the Baskervilles. Set in today's Los Angeles, the novel I.Q, named after its main protagonist, the black detective Isaiah Quintabe, pays an irreverent homage to Conan 
Doyle, introducing parody and comedy into "hard-boiled" crime fiction. Blin-Cordon shows the plasticity of the holmesian myth, focusing on how contemporary Sherlockiana is vivified by mass media culture. References are made to Coppola's Godfather, to Denzel Washington's impersonation of Civil Rights activist Malcolm X onscreen. Rap culture is also conjured up. Such a figure from the past as Sherlock is not only thus modernised, or updated, our modern popular culture is also, definitely, "Sherlocked"!

Victorian texts are often seen as holding a mirror up to fantasies and anxieties about the British Empire-expressed through the fear of foreign invasion and the fascination and repulsion for the oriental, "exotic" Other, often feminised and sexualised. The final section of this cluster of essays, "The Empire Strikes Back", provides two perspectives on the Neo-Victorian re-scripting of Victorian fears and fantasies in contemporary productions and on the neo-colonialism that characterises our globalised contemporary world. Jaine Chemmachery demonstrates how the depiction of London in some Neo-Victorian productions-the TV series Sherlock (2010-) and Penny Dreadful (2014-2016), the graphic novel From Hell by Alan Moore and Eddie Campbell-partakes of a "Neo-Victorientalist" strategy and are thus reminiscent of Edward Said's theorisation of Orientalism. She unveils the ideologically and politically-albeit probably unintentional-problematic dimension of such Neo-Victorian works and thereby sheds light on the tainted legacy of the Victorians for our times. Similarly, Nolwenn Corriou argues that the 2017 film The Return of the Mummy by Alex Kurtzman is a neo-Orientalist tale unearthing and reactivating the tropes of Victorian and Edwardian "mummy fiction": the revived (female) mummy is an embodiment of a radical otherness endlessly threatening the values of the West.

Beyond the exploration of a taste for retro, of a paralysing backward-looking glance, or of a binary opposition between nostalgia and critical engagement, the 11 essays delineate dialectic relations between past and present, "popular cultures" and literary texts. They show what the persistence of things Victorian tells us about our contemporary society and ethos, and highlight the complexity of our engagement with the Victorian past, which, contrary to what Ezra Pound predicted in 1918, we twentyfirst century citizens certainly do not appear content to leave behind.

\section{BIBLIOGRAPHY}

Agamben, Giorgio. "What Is the Contemporary?" What Is an Apparatus? and Other Essays.

Trans. David Kishik and David Pedatella. Stanford, CA: Stanford UP, 2009, 39-54.

Barthes, Roland. "The Death of the Author" (1968). Image-Music-Text. Trans. Stephen Heath. New York: Hill and Wang, 1977.

Benjamin, Walter. The Arcades Project. Trans. Howard Eiland and Kevin McLaughlin. Cambridge, Mass./London: The Belknap Press of Harvard UP, 1999.

Ellmann, Richard. Oscar Wilde. London: Hamish Hamilton, 1987. 
Fennetaux, Ariane. "Birds of a Feather: Alexander McQueen's Victorian Bestiary". Cahiers victoriens et édouardiens 88 (automne 2018), http://journals.openedition.org/cve/4328, last accessed 27 May 2020.

Gutleben, Christian and Susan Onega. Introduction to Refracting the Canon in Contemporary British Literature and Film. Christian Gutleben and Susan Onega (eds.). Amsterdam/New York: Rodopi, 2004, 7-15.

Heilmann, Ann and Mark Llewellyn. Neo-Victorianism. The Victorians in the Twenty-First Century, 1999-2009. Houndmills: Palgrave Macmillan, 2010.

Hollinghurst, Alan. The Stranger's Child. London: Picador, 2011.

Hutcheon, Linda. A Theory of Parody. New York/London: Methuen, 1985.

Jenkins, Henry. “Transmedia 202: Further Reflections”. Confessions of an Aca-Fan: The Official Weblog of Henry Jenkins. 1 August 2011. http://henryjenkins.org/blog/2011/08/ defining_transmedia_further_re.html, last accessed 19 May 2017.

Jenkins, Henry. Textual Poachers. Television Fans and Participatory culture. New York/ London: Routldege, 2013.

Mayer, Ruth. Serial Fu Manchu: The Chinese Supervillain and the Spread of Yellow Peril Ideology. Philadelphia: Temple UP, 2014.

Mikowski, Sylvie and Yann Philippe (eds.). Popular Cultures Today. Imaginaires 19 (2015).

Mikowski, Sylvie and Yann Philippe (eds.). How Popular Culture Travels: Cultural Exchanges Between Ireland and the USA. Imaginaires 22 (2019).

Mitchell, Kate. History and Cultural Memory in Neo-Victorian Fiction: Victorian Afterimages. Basingstoke: Palgrave Macmillan, 2010.

Said, Edward. Orientalism (1978). New York: Vintage Books, 2003.

Shiller, Dana. “The Redemptive Past in the Neo-Victorian Novel”. Studies in the Novel 29.3 (winter 1997): 538-560.

Shuttleworth, Sally. "Natural History: The Retro-Victorian Novel". The Third Culture: Literature and Science. Elinor Schaffer (ed.). Berlin: De Gruyter, 1998.

Solicari, Sonia (ed.). Victoriana: A Miscellany. Accompanying publication to the exhibition at the Guildhall Art Gallery ( $7^{\text {th }}$ September to $8^{\text {th }}$ December 2013). London: Guildhall Art Gallery, 2013.

Tennyson, Alfred. In Memoriam (1849). Selected Poems. Christopher Ricks (ed.). London: Penguin Classics, 2007, 96-199.

\section{NOTES}

1. The reference to Tennyson is present right from the title of the novel, as "the stranger's child" is a snippet from Tennyson's In Memoriam (1849; section CI, Tennyson 172), a pastoral elegy for the poet's close friend Arthur Hallam.

2. Steampunk is originally a subgenre of science-fiction which typically incorporates nineteenthcentury steam-powered machinery; steampunk has ramifications in fashion, music, TV series and films. The term steampunk was coined in the late 1980s, in reference to cyberpunk (a subgenre of science-fiction set in a dystopian future which features high-tech elements). 


\section{INDEX}

Mots-clés: néo-victorien, culture populaire, néo-orientalisme, remédiation, transmédiation, série TV, jeu vidéo, film, comédie musicale, roman policier

Keywords: neo-Victorian, popular culture, neo-Orientalism, remediation, transmediation, TV series, video game, film, musical, detective fiction

\section{AUTHORS}

\section{YANNICK BELLENGER-MORVAN}

Yannick Bellenger-Morvan is Associate Professor at the English Department of the University of Reims Champagne-Ardenne, France. She has published about twenty peer-reviewed academic papers on popular culture for children, teenagers, and young adults. She co-edited a collection of essays on Children's literature and Popular Cultural Identity (Reims University Press, 2016). Her latest publications include articles on Jim Henson's TV series Fraggle Rock (in Children, Youth and American Television, Routledge, 2018) and on animated film adaptations of Roald Dahl's novels (Les Cahiers Robinson, Artois University Press, April 2020). She also edited an annotated and critical translation of Victorian author George MacDonald's fairy tales (George MacDonald, La Princesse légère et autres contes, Héritages Critiques, vol. IX, Reims University Press, 2019).

\section{XAVIER GIUDICELLI}

Xavier Giudicelli is Associate Professor at the English Department of the University of Reims Champagne-Ardenne, France. He has authored a monograph entitled Portraits de Dorian Gray : le texte, le livre, l'image (Presses de l'université Paris-Sorbonne, 2016). He has co-edited or edited around 10 volumes or journal issues, including a collection of essays on Wilde's The Importance of Being Earnest in 2014 and an issue of Études anglaises on Wilde and the arts in 2016. He has also published about twenty peer-reviewed journal articles and book chapters on book illustration/ word and image studies, the rewriting and reinterpretation of Victorian and Edwardian literature in the twentieth and twenty-first centuries, translation and cultural transfers in fin-desiècle art and literature, Oscar Wilde, E.M. Forster and Alan Hollinghurst. 